$2012-10$

\title{
Sea anemones may thrive in a high CO2 world
}

Suggett, DJ

http://hdl.handle.net/10026.1/1332

10.1111/j.1365-2486.2012.02767.x

GLOBAL CHANGE BIOLOGY

Wiley

All content in PEARL is protected by copyright law. Author manuscripts are made available in accordance with publisher policies. Please cite only the published version using the details provided on the item record or document. In the absence of an open licence (e.g. Creative Commons), permissions for further reuse of content should be sought from the publisher or author. 


\title{
Sea anemones may thrive in a high $\mathrm{CO}_{2}$ world
}

\author{
DAVID J.SUGGETT*, JASON M. HALL-SPENCER $†$, RICCARDO RODOLFO-METALPA $\uparrow$, \\ TOBYG. BOATMAN*, ROSS PAYTON*, D. TYE PETTAY , VIVIENNER. JOHNSON $†$, MARK \\ E. WARNER $\ddagger$ and TRACY LAWSON* \\ ${ }^{*}$ Coral Reef Research Unit, School of Biological Sciences, University of Essex, Colchester, CO4 3SQ, UK, †Marine Biology and \\ Ecology Research Centre, University of Plymouth, Plymouth, PL4 8AA, UK, \$College of Earth, Ocean, and Environment, \\ University of Delaware, 700 Pilottown Road, Lewes, Delaware 19958, USA
}

\begin{abstract}
Increased seawater $p \mathrm{CO}_{2}$, and in turn 'ocean acidification' (OA), is predicted to profoundly impact marine ecosystem diversity and function this century. Much research has already focussed on calcifying reef-forming corals (Class: Anthozoa) that appear particularly susceptible to OA via reduced net calcification. However, here we show that OA-like conditions can simultaneously enhance the ecological success of non-calcifying anthozoans, which not only play key ecological and biogeochemical roles in present day benthic ecosystems but also represent a model organism should calcifying anthozoans exist as less calcified (soft-bodied) forms in future oceans. Increased growth (abundance and size) of the sea anemone (Anemonia viridis) population was observed along a natural $\mathrm{CO}_{2}$ gradient at Vulcano, Italy. Both gross photosynthesis $\left(P_{\mathrm{G}}\right)$ and respiration $(\mathrm{R})$ increased with $p \mathrm{CO}_{2}$ indicating that the increased growth was, at least in part, fuelled by bottom up $\left(\mathrm{CO}_{2}\right.$ stimulation) of metabolism. The increase of $P_{\mathrm{G}}$ outweighed that of $\mathrm{R}$ and the genetic identity of the symbiotic microalgae (Symbiodinium spp.) remained unchanged (type A19) suggesting proximity to the vent site relieved $\mathrm{CO}_{2}$ limitation of the anemones' symbiotic microalgal population. Our observations of enhanced productivity with $p \mathrm{CO}_{2}$, which are consistent with previous reports for some calcifying corals, convey an increase in fitness that may enable non-calcifying anthozoans to thrive in future environments, i.e. higher seawater $\mathrm{pCO}_{2}$. Understanding how $\mathrm{CO}_{2}$-enhanced productivity of non- (and less-) calcifying anthozoans applies more widely to tropical ecosystems is a priority where such organisms can dominate benthic ecosystems, in particular following localized anthropogenic stress.
\end{abstract}

Keywords: Cnidarian, $\mathrm{CO}_{2}$ vent, Ocean acidification, Productivity, Sea anemone, Symbiodinium spp.

Received 5 April 2012 and accepted 5 June 2012

\section{Introduction}

Rising atmospheric $\mathrm{CO}_{2}$ from anthropogenic activity will significantly increase seawater $\mathrm{CO}_{2}$ partial pressure $\left(p \mathrm{CO}_{2}\right)$ and result in lower ocean $\mathrm{pH}$ or 'ocean acidification' (OA) this century (Caldeira \& Wickett, 2005). Predictions suggest that by the year 2100 surface ocean $\mathrm{pH}$ could be reduced by ca. $0.3-0.5$ units compared to present day values (IPCC, Intergovernmental Panel on Climate Change, 2007), with profound consequences for fundamental biological processes, such as calcification and photosynthesis, and in turn the functioning of entire marine ecosystems (e.g. Hoegh-Guldberg \& Bruno, 2010). The potential impact of OA upon corals reefs has particularly received much high profile attention. Coral reef ecosystems are characterized by high productivity and diversity as a result of primary productivity and calcification by coral cnidari-

Correspondence: David J. Suggett, tel. + 4401206872 552,

fax + 4401206872 592, e-mail: dsuggett@essex.ac.uk ans (Class: Anthozoa). Observations from laboratory experiments attempting to replicate future OA scenarios (e.g. Anthony et al., 2008; Edmunds et al., 2012) as well as in situ investigations at present day naturally high $\mathrm{CO}_{2}$ shallow water reefs (Fabricius et al., 2011; Crook et al., 2012), generally demonstrate that calcification and growth will be impacted by elevated $\mathrm{CO}_{2}$ (reduced pH) (see also Andersson et al., 2011). However, the evidence is not entirely negative:

A growing volume of studies suggest that net calcification rates may in fact not always be reduced under long-term exposure to elevated $\mathrm{CO}_{2}$ (Krief et al., 2010; Rodolfo-Metalpa et al., 2010). Some calcifiers, including coral cnidarians (Rodolfo-Metalpa et al., 2011) can maintain intact their calcification rates at extremely low $\mathrm{pH}$ levels, most likely via tissues and other organic layers acting as a barrier to the surrounding seawater and thus reducing dissolution. Furthermore, even where calcification and growth rates are decreased, calcifying coral cover can remain high since some species are still able to survive in high $\mathrm{CO}_{2}$ environments (e.g. 
Porites lutea, Fabricius et al., 2011; see also Crook et al., 2012). Even more intriguing is the fact that coral primary productivity can often increase (or is unaffected) while net calcification decreases/dissolution increases for some OA scenarios (e.g. Crawley et al., 2010); consequently, anthozoans can potentially remain completely viable, but as alternative non-calcifying soft-bodied forms under extremely high $\mathrm{CO}_{2} /$ low $\mathrm{pH}$ (Fine \& Tchernov, 2007; see also Krief et al., 2010). However, how such OA-driven phenotypic responses alter the functional role of soft-bodied forms of anthozoans, or even convey longer term ecological success, is presently unknown. Such limited knowledge still reflects the fact that we do not fully understand how present day noncalcifying anthozoans, will respond to OA. Non-calcifying anthozoans such as soft corals and anemones, play important ecological and biogeochemical roles in reef environments (e.g. Fitt et al., 1982; Bak \& Borsboom, 1984; Muller-Parker \& Davy, 2001), but much less is known how these organisms will respond to OA (Doherty, 2009; Towanda \& Thuesen, 2012) given a present bias in OA research towards calcifying organisms (Connell \& Russell, 2010).

As with reef-forming scleractinian corals, many anemones (Class: Anthozoa, Subclass: Hexacorallia) harbour symbiotic algae (Symbiodinium spp.) to supplement their nutritional requirements. However, in contrast to calcifying corals, anemones are fast growing and easier to manipulate via the lack of tissue adhesion to an underlying skeleton; thus anemones are potentially model organisms for understanding the nature with which environmental change, including OA, may impact reef-forming cnidarians (e.g. Muller-Parker \& Davy, 2001; Weis et al., 2008). Here we present the findings of the first in situ assessment of the effects of OA on anemones whereby elevated $\mathrm{CO}_{2}$ can enhance productivity, and in turn growth, and community dominance of anemones within a natural benthic ecosystem.

A major limitation for almost all OA studies to date has been replicating the rate (decades) and biological scale (ecosystems) at which OA operates. However, natural $\mathrm{CO}_{2}$ vents at coastal sub-tropical rocky shores (Hall-Spencer et al., 2008; Kroeker et al., 2011; Meron et al., 2012) and tropical coral reefs (Fabricius et al., 2011) provide unique experimental settings to evaluate relatively long term changes in $p \mathrm{CO}_{2}(\mathrm{pH})$ across many biological and spatial scales. The few studies conducted to date at $\mathrm{CO}_{2}$ vent sites have generally revealed a decrease in calcifying invertebrate and macroalgal abundance and increased contribution of non-calcifying macroalgae and/or seagrass to overall benthic cover (Hall-Spencer et al., 2008; Fabricius et al., 2011); such changes again correspond to the elevated $\mathrm{CO}_{2}$ (lower $\mathrm{pH}$ ) induced reduction of calcification and/ or enhanced shell dissolution in the dominant invertebrates (including gastropods and hermatypic corals; Hall-Spencer et al., 2008; Rodolfo-Metalpa et al., 2011).

We present novel observations across a natural coastal $\mathrm{CO}_{2}$ gradient from a shallow cold vent system (Vulcano, Italy) (Johnson et al., 2011, 2012) supporting previous observations from other vent sites that certain invertebrates increase in abundance with increasing $p \mathrm{CO}_{2} /$ decreasing $\mathrm{pH}$ (Cigliano et al., 2010; Kroeker et al., 2011). Here, anemone (Anemonia viridis) abundance increased with $p \mathrm{CO}_{2}$, and dominated the invertebrate community at high $p \mathrm{CO}_{2}$ conditions. We tested the hypothesis that their increased dominance was driven (bottom up) via enhanced anemone productivity. Physiological analyses demonstrated an increase of gross maximum photosynthesis $\left(P_{G}^{\max }\right)$ and respiration rates (R) (but with $P_{G}^{\max }>\mathrm{R}$ ) as well as increased dinoflagellate endosymbiont abundance (but unchanged diversity) with increasing $p \mathrm{CO}_{2}$. Our observations are the first to show that non-calcifying anthozoans can be actively selected for under OA conditions and thus it is essential that greater focus is given to better understand how this previously neglected group will contribute to ecosystem scale productivity and nutrient cycling in future oceans.

\section{Materials and methods}

\section{Sample site environment and benthic community analyses}

Data collection was conducted in the sublittoral of North Vulcano Island ( $\left.38^{\circ} 25^{\prime} \mathrm{N}, 14^{\circ} 57^{\prime} \mathrm{E}\right) \mathrm{ca} .25 \mathrm{~km}$ North East of Sicily, 11th to 26th May 2011. Several vents naturally release $\mathrm{CO}_{2}$ in coastal waters here as a result of the close proximity to Vulcano's active volcano (described previously, Johnson et al., 2011, 2012). As with recent investigations from this site (Johnson et al., 2012) we selected three reference sites (R1-3) away from the vents, and hence representative of 'present day' $p \mathrm{CO}_{2}$ conditions, and three sites (S1-3) with increasing proximity to the vents; together these six sites provided a gradient of decreasing $\mathrm{pH}$ (increasing $p \mathrm{CO}_{2}$ ) from ca. 8.2 (365 $\mu \mathrm{atm}$ ) at to $7.6(1425 \mu \mathrm{atm})$ (see Table 1). Full details of the carbonate chemistry (and associated methodology) for these six sites are given in Johnson et al. (2012). Variability in the carbonate system also increases with proximity to the vents (Table 1), a factor that is also discussed further in Johnson et al. (2012).

All sample sites were shallow (1-2m) and investigated between 10:00 and 12:00 local time. Water temperature was measured using a $\mathrm{HOBO}^{\circledR}$ logger (Tempcon, USA) throughout the sampling period and was constant across all sites at ca. 20.6-21.4 ${ }^{\circ} \mathrm{C}$ (data not shown). Light attenuation $\left(\mathrm{K}_{\mathrm{d}}\right.$ [PAR], $\mathrm{m}^{-1}$ ) within the upper $1-2 \mathrm{~m}$ was measured via the light sensor of a Diving-PAM (Pulse Amplitude Modulated) fluorometer (Walz $\mathrm{GmbH}$, Germany) as described previously by Hennige et al. (2008), and also remained constant between 


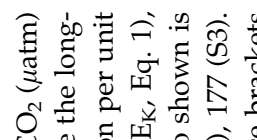

U.

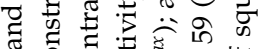

Q

छ

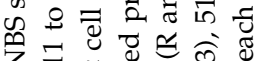

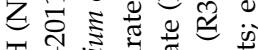

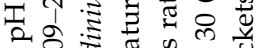

×

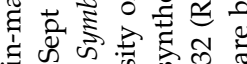

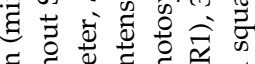

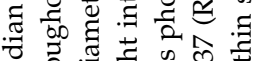

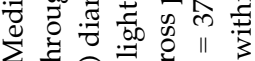

过䓽

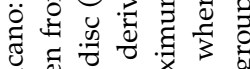

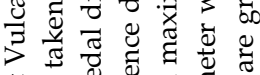

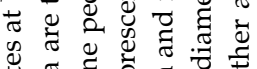

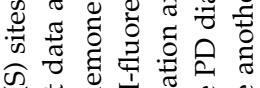

की

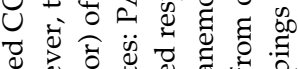

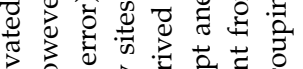

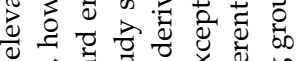

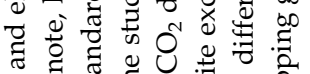

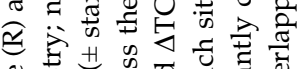

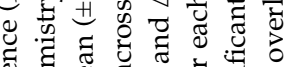

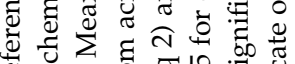

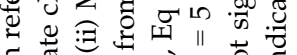

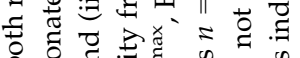

일

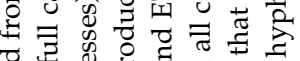

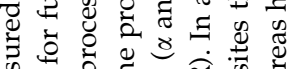

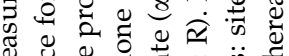

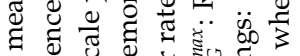

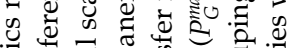

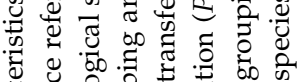

敋

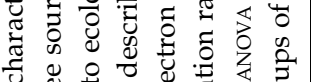

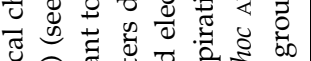

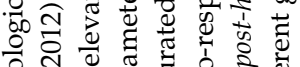

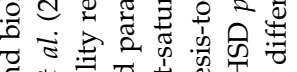

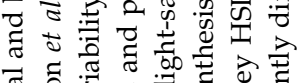

త

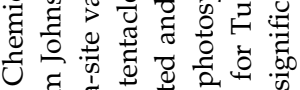

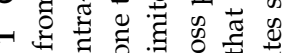

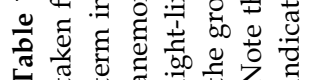

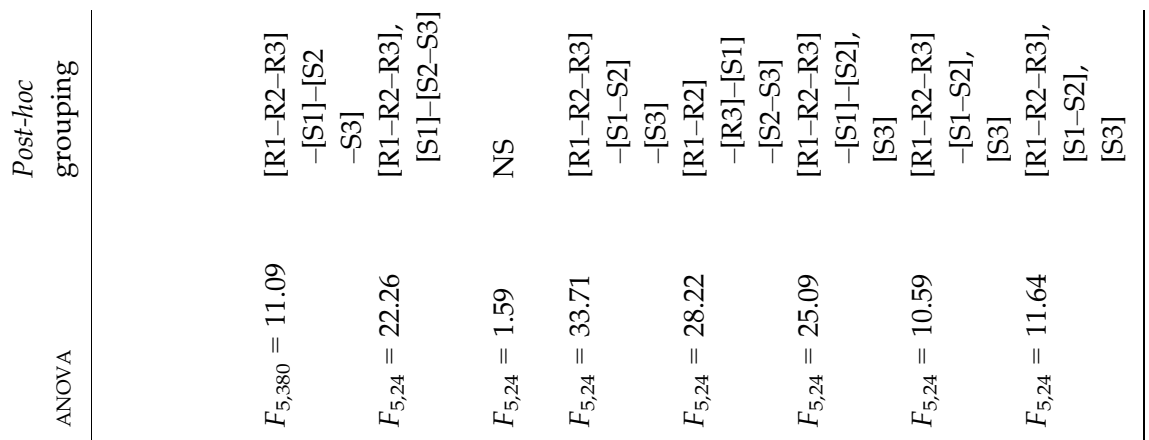

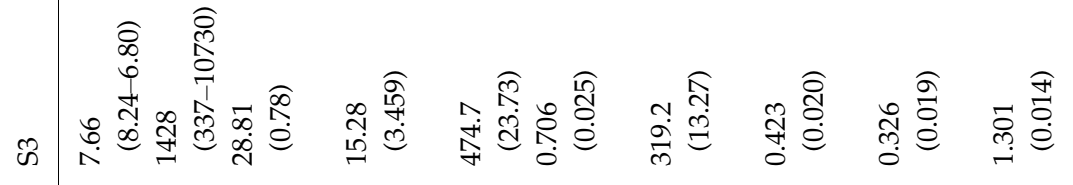

芯

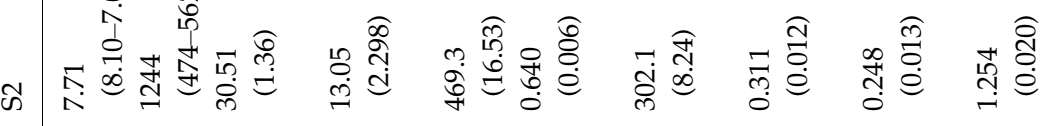

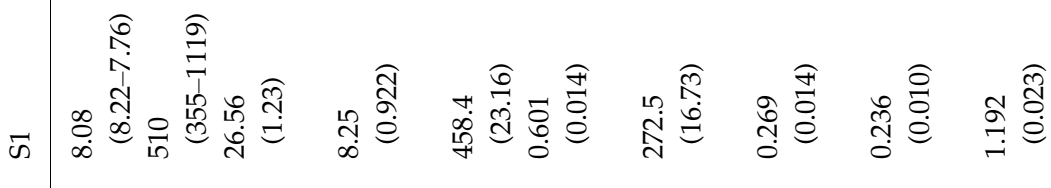

๙

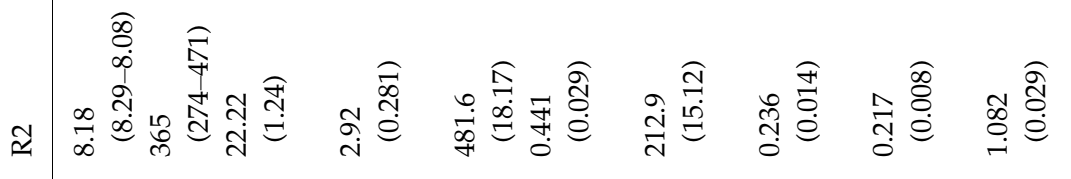

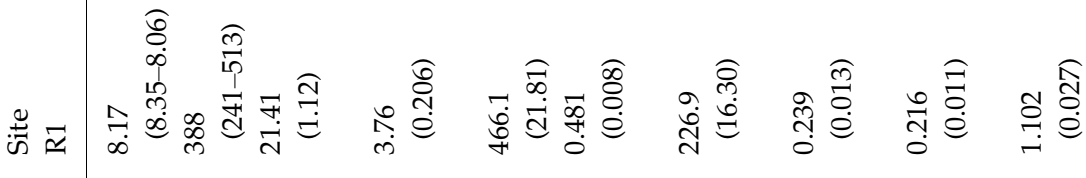

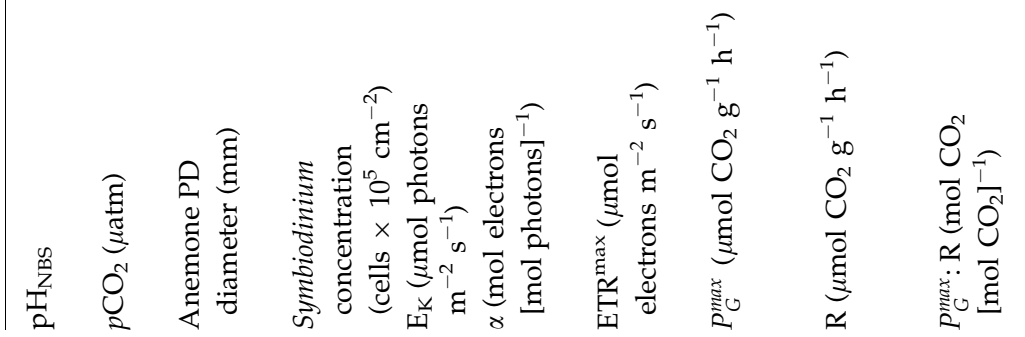


sites, at $0.27-0.33 \mathrm{~m}^{-1}$. Therefore, temperature and light availability were not further considered as environmental factors significantly contributing to any ecological/physiological differences between sites.

Benthic assemblages for each of the six sites were assessed using a visual census method ca. $0.0-0.3 \mathrm{~m}$ below low water. A quadrat measuring $0.25 \mathrm{~m}^{2}$ was randomly placed for quantifying sea urchin (Paracentrotus lividus, Arbacia lixula) and anemone (A. viridis and Actinia equina) abundance; a total of 20 separate counts (per $0.25 \mathrm{~m}^{2}$ ) were made at each site. Continuous-line intercept transects ( $n=3$ per site) of $20 \mathrm{~m}$ were further used for general characterization of the relative (\%) cover of the major benthic groups (canopy forming macroalgae, e.g., Sargassum vulgare, Cystoseira spp., seagrass, sessile invertebrates etc.). Pedal disc size of all anemones located up to $0.5 \mathrm{~m}$ either side of the transect (to yield a $20 \mathrm{~m}^{2}$ belt transect) were subsequently measured with vernier callipers (precision, $0.1 \mathrm{~mm}$ ); dimensions reported here are the mean length and width.

\section{Anemone productivity}

Anemones $(n=5)$ were randomly collected from each site and returned to the laboratory for subsequent examination of productivity via two complementary approaches; specimens from each site were examined on consecutive days: Active chlorophyll $a$ fluorescence rapid light curves (RLCs) initially provided estimates of photosynthetic activity (as the electron transfer rate, ETR) whilst $\mathrm{TCO}_{2}$-drift measurements in the light and dark subsequently provided corresponding rates of primary production and respiration. All anemones were initially blotted dry and wet-weighed (Technico-PW01 balance, $\pm 0.01 \mathrm{~g})$ and then maintained in aquaria with seawater filled from the corresponding sample site. Specimens were returned to the original site of collection to minimize the length of time ex situ post examination.

Rapid light curves, RLCs were collected using a divingPAM programmed according to settings described previously (Hennige et al., 2008; Suggett et al., 2012) to deliver nine light steps of $20 \mathrm{~s}$ duration with increasing intensity from 0 to ca. $3000 \mu \mathrm{mol}$ photons $\mathrm{m}^{-2} \mathrm{~s}^{-1}$. Optimum instrument sensitivity (gain) and induction intensity (saturation width and intensity) were verified prior to each RLC and all anemones were dark acclimated for ca. 1-2 h prior to examination. Each light step yielded a measure of the minimum and maximum fluorescence yield ( $F^{\prime}$ and $F_{m}{ }^{\prime}$, respectively, instrument units) from which the photochemical efficiency $\left(\left[F_{m}{ }^{\prime}-F^{\prime}\right] / F_{m}{ }^{\prime}=F_{q}{ }^{\prime} / F_{m}{ }^{\prime}\right.$, dimensionless) could then be determined. An equation describing the light-dependency of the photochemical efficiency (Hennige et al., 2008) was then fit using least squares non-linear regression to the RLC measures of $F_{q}{ }^{\prime} / F_{m}{ }^{\prime}$,

$$
F_{q}^{\prime} / F_{m}^{\prime}=\left[\left(F_{q}^{\prime} / F_{m}^{(\max )} E_{K}\right)\left(1-\exp \left(-E / E_{K}\right)\right)\right] / E
$$

where $\mathrm{E}$ is the light intensity for each light step ( $\mu \mathrm{mol}$ photons $\mathrm{m}^{-2} \mathrm{~s}^{-1}$ ), $\mathrm{E}_{\mathrm{k}}$ is the saturation light intensity ( $\mu \mathrm{mol}$ photons $\mathrm{m}^{-2} \mathrm{~s}^{-1}$ ) and $F_{q}{ }^{\prime} / F_{m}{ }^{(\max )}$ is the maximum PSII photochemical efficiency (dimensionless). Mean values for $E_{k}$
(Table 1) and $F_{q}{ }^{\prime} / F_{m}{ }^{\prime(\max )}$ (data not shown) were not different between sites suggesting a uniform extent of photoacclimation (e.g. Suggett et al., 2009, 2012), and thus confirming that differences in light availability across the sites/sampling period were negligible.

Photosynthetic electron transport rate (ETR, $\mu$ mol electrons $\mathrm{m}^{-2} \mathrm{~s}^{-1}$ ) was subsequently determined for each light step from the product of $\mathrm{E}, F_{q}{ }^{\prime} / F_{m}{ }^{\prime}$ and a constant factor of 0.5 (Hennige et al., 2008); this factor accounts for assumptions that only $50 \%$ of all absorbed photons are utilized by PSII and that the quantum yield electron transfer of a trapped photon within a reaction centre is $1 \mathrm{~mol}$ electron [mol photon] ${ }^{-1}$ (see Suggett et al., 2011, 2012). In this case ETRs do not include quantitative information as to the extent of light absorbed and are therefore relative. ETR values from each RLC were fit to a modified equation describing the light-dependency of photosynthesis (see Hennige et al., 2008) using non-linear least squares regression,

$$
E T R=E T R^{\max }\left(1-\exp \left(-\alpha E / E T R^{\max }\right)\right)
$$

where $\alpha$ (mol electrons [mol photons] ${ }^{-1}$ ) and ETR $^{\max }$ ( $\mu \mathrm{mol}$ electrons $\mathrm{m}^{-2} \mathrm{~s}^{-1}$ ) describe the light-limited and lightsaturated electron transfer rate respectively.

Anemones were subsequently transferred to one of $5 \times 100 \mathrm{~mL}$ glass Duran bottles filled with seawater from the corresponding site for $\mathrm{TCO}_{2}$ drift determinations. Two additional bottles were filled with seawater alone to provide a simultaneous control of any $\mathrm{TCO}_{2}$ drift induced by activity other than the anemones since the seawater was unfiltered. Lids for the bottles were pre drilled to fit the $\mathrm{pH}$ and temperature probes (Hydrocheck CD7000; WPA Ltd. Cambridge, UK; $\mathrm{pH} \pm 0.01$ and ${ }^{\circ} \mathrm{C} \pm 0.1$ ) and set to log every 15 min over a 90 min incubation period; the $\mathrm{pH}$ sensor was calibrated daily using pre-made $\mathrm{N}_{\text {IST }}$ buffer solutions ( $\mathrm{pH} 4.0$ and 7.0, Hanna Instruments, Leighton Buzzard, UK) to yield $\mathrm{pH}$ total scale $\left(\mathrm{pH}_{\mathrm{T}}\right)$ measurements. All bottles were placed in a makeshift water bath where water was changed every $15 \mathrm{~min}$ and mixed with additional refrigerated water $\left(4{ }^{\circ} \mathrm{C}\right)$ to maintain the temperature within $1-2^{\circ} \mathrm{C}$ of that in situ at the time of sampling $\left(\sim 21^{\circ} \mathrm{C}\right)$. All vessels were incubated outdoors (under natural light), and covered with neutral density filter to provide intensities similar to those in situ (ca. $600-1000 \mu \mathrm{mol}$ photons $\mathrm{m}^{-2} \mathrm{~s}^{-1}$ at noon local time), to determine maximum net photosynthesis rates (e.g. Anthony et al., 2008). Incubations were performed between 12:00 and 13:30 (local time), and subsequently repeated in darkness after sunset (20:00-21:30, local time) to determine corresponding respiration rates.

Measurements of temperature, salinity, $\mathrm{pH}_{\mathrm{T}}$ along with those for total alkalinity (TA) for each site (see Johnson et al., 2012), were used to calculate the total concentration of inorganic carbon $\left(=\mathrm{TCO}_{2}, \mu \mathrm{mol} \mathrm{CO} \mathrm{L}^{-1}\right.$, as the sum of free $\mathrm{CO}_{2}$, $\mathrm{HCO}_{3}{ }^{-}$and $\mathrm{CO}_{3}{ }^{2-}$ ) via CO2SYS software (Lewis \& Wallace, 1998) using the constants of Roy et al. (1993) and Dickson (1990) for $\mathrm{KSO}_{4}$. The concentration of $\mathrm{TCO}_{2}$ was determined at the start and end of each incubation and we assumed that TA did not significantly vary during the drifts since the dominant biology, the anemones, are non-calcifying. Rates of maximum 
net photosynthesis and respiration $\left(P_{G}^{\max }\right.$ and $\mathrm{R}$, $\mu \mathrm{mol} \mathrm{CO} \mathrm{C}^{-1} \mathrm{~h}^{-1}$ ) were subsequently calculated as,

$$
P_{N}^{\max }(R)=\left[\left(\delta \mathrm{TCO}_{2}(\text { sample })-\delta \mathrm{TCO}_{2}(\text { control })\right) v\right] /(\delta \mathrm{Tw})
$$

where $v$ and $w$ are the water volume (L) and anemone wet weight (g) while $\Delta \mathrm{T}$ and $\Delta \mathrm{TCO}_{2}$ are the difference of time (h) and $\mathrm{TCO}_{2}\left(\mu \mathrm{mol} \mathrm{CO} \mathrm{CO}^{-1}\right)$ at the start and end of incubation; the mean of both $\Delta \mathrm{TCO}_{2}$ (control) values was subtracted from each $\Delta \mathrm{TCO}_{2}$ (sample). Respiration rates were multiplied by a factor of -1 to yield positive values. Maximum gross photosynthesis rates $\left(P_{G}^{\max }, \mu \mathrm{mol} \mathrm{CO}_{2} \mathrm{~g}^{-1} \mathrm{~h}^{-1}\right)$ were finally calculated as $P_{G}^{\max },=P_{N}^{\max }+\mathrm{R}$.

\section{Microalgal symbiont characteristics}

Cellular density and the genetic characterization by ITS-2 (internal transcribed spacer region-2) of the anemone's microalgal endosymbiont (Symbidinium spp.) were determined to support interpretation of any potential changes in anemone productivity. Small tentacle samples were randomly removed from each anemone used to determine productivity. Tentacle surface area $\left(\mathrm{SA}_{\mathrm{T}}, \mathrm{cm}^{-2}\right)$ of the sample was measured again using vernier callipers prior to storage in glutaraldehyde (1\%). Each tentacle sample was later ground in hand-held, glass tissue-homogenizers in water $\left(0.6 \mathrm{~mL}=\mathrm{V}_{\mathrm{T}}\right)$ and an aliquot transferred to a haemocytometer for cell counts (eight counts per sample) using light microscopy. Symbiodinium density (cells $\mathrm{cm}^{-2}$ ) was thus determined as,

$$
\text { Cells } \mathrm{cm}^{-2}=\text { cells } \mathrm{mL}^{-1} \cdot\left(\mathrm{V}_{\mathrm{T}} / \mathrm{SA}_{\mathrm{T}}\right)
$$

Nucleic acid extractions were conducted using a modified Promega Wizard genomic DNA extraction protocol (following LaJeunesse et al., 2003). Symbiont identity was characterized by denaturing gradient gel electrophoresis (DGGE) fingerprinting of the partial $5.8 \mathrm{~S}$ and internal transcribed spacer (ITS) region 2 (LaJeunesse, 2002); this region was amplified using a touch-down thermal cycle profile with the primers 'ITS2clamp' and 'ITSintfor2' (LaJeunesse \& Trench, 2000), and the PCR products resolved on denaturing gels (45-80\% of $7 \mathrm{M}$ urea \& $40 \%$ formamide) using a CBScientific system (Del Mar, CA, USA) for $16 \mathrm{~h}$ at 115 volts. The dominant band of the DGGE profile was excised, re-amplified and cycle sequenced to provide the ITS2 sequence that dominated the symbiont's genome.

\section{Results}

\section{Benthic community structure and anemone distribution}

Total macroalgal cover (canopy forming macroalgae, as a $\%$ of total benthic cover) during the anemone and urchin surveys was generally higher for the elevated $\mathrm{CO}_{2}$ sites, ca. 40-60\%, than at the reference sites, ca. 20-30\% (Fig. 1). However, cover at the site with the highest $p \mathrm{CO}_{2}$ (S3) was not significantly different from that at R3 (see Fig. 1 legend for ANOVA results). Increased macroalgal cover was accompanied by a change in dominance from both calcifying and noncalcifying species at the reference sites (not shown) to fleshy macroalgal cover at the high $\mathrm{CO}_{2}$ sites (phaeophytes, Johnson et al., 2012).

Reciprocal changes were observed between the sea urchin (Arbacia lixula and P. lividus) and anemone (A. viridis) population abundances for the reference vs. high $\mathrm{CO}_{2}$ sites. Both sea urchin species exhibited consistent abundances, ca. $1-2 \mathrm{~m}^{2}{ }^{2}(P$. lividus) and $4-$ $6 \mathrm{~m}-^{2}$ (A. lixula), across the reference sites but were completely absent from any of the higher $\mathrm{CO}_{2}$ sites (see also Johnson et al., 2012). In contrast, A. viridis abundance remained consistent (of ca. $10 \mathrm{~m}-{ }^{2}$ ) across the reference sites but significantly increased to ca. 20 and $40 \mathrm{~m}-{ }^{2}$ at sites S1-S2 and S3 respectively (see Fig. 1). In addition to abundance, $A$. viridis size (pedal disc) increased from ca. $21-23 \mathrm{~mm}$ at the reference sites to

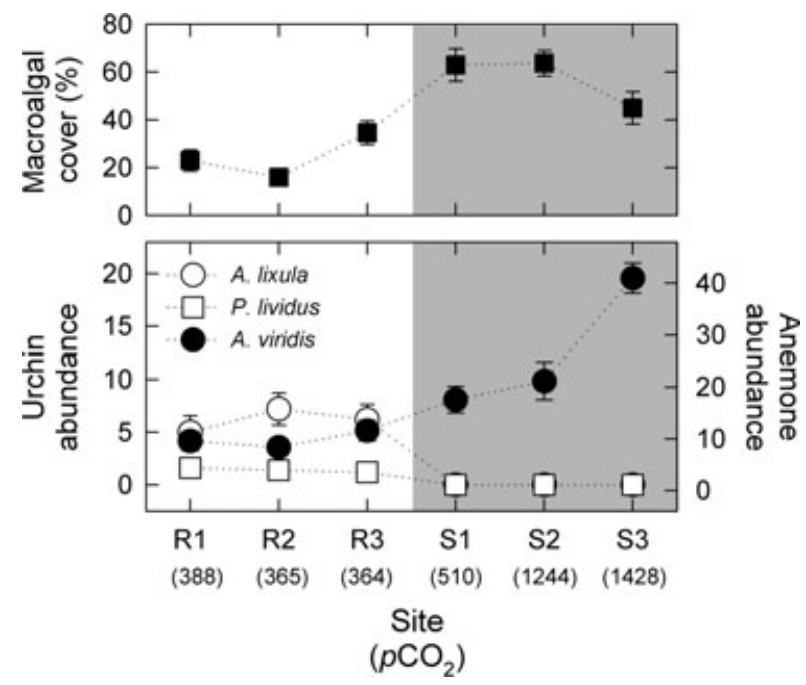

Fig. 1 Mean ( \pm standard error) of (i) Canopy forming macroalgal cover (\% of total benthic cover) and (ii) Sea urchin (Arbacia lixula and Paracentrotus lividus) and anemone (Anemonia viridis) abundance (no. per $\mathrm{m}^{2}$ ) from the reference (R) and elevated $\mathrm{CO}_{2}$ (S) sites at Vulcano; note that the median $p \mathrm{CO}_{2}$ (Table 1) for each site is given in parentheses below each site. Macroalgal cover was collected from $n=6$ continuous-line intercept transects per site; note that significant differences were assessed using ANOVA after arcsin transforming the \% (proportion) cover data: $F_{5,30}=36.88$ with sites grouped via the post hoc Tukey test (as described in the legend for Table 1) as [R1-R2]-[R3-S3]-[S1S2]. Urchin and anemone abundance data were collected from 20 quadrat counts per site. ANOVAs upon the untransformed count data were not significant for the two urchin species; however, the ANOVA for $A$. viridis was $\mathrm{F}_{5,114}=23.49$ with sites grouped as [R1-R2-R3]-[S1-S2], [S3]. 
ca. 27-31 $\mathrm{mm}$ at the higher $\mathrm{CO}_{2}$ sites (Table 1). The largest anemones were observed at sites S2-S3.

\section{Anemone productivity}

Light-limited $(\alpha)$ and light saturated ETRs (ETR $\left.{ }^{\max }\right)$ as well as the maximum gross photosynthesis rate $\left(P_{G}^{\max }\right)$ generally increased from the reference to the high $\mathrm{CO}_{2}$ sites (Table 1; also Fig. 2a). Values for $\alpha$, ETR $^{\max }$ and $P_{G}^{\max }$ were ca. $0.4-0.5 \mathrm{~mol}$ electrons [mol photons] ${ }^{-1}$, 210-250 $\mu \mathrm{mol}$ electrons $\mathrm{m}^{-2} \mathrm{~s}^{-1}$ and $0.22 \mu \mathrm{mol} \mathrm{CO}_{2}$ $\mathrm{g}^{-1} \mathrm{~h}^{-1}$, for the ambient $p \mathrm{CO}_{2}$ reference sites (R1-3, Table 1); as with anemone size (above), values for these parameters describing primary productivity all increased by ca.10-20\% at S1 but were not statistically
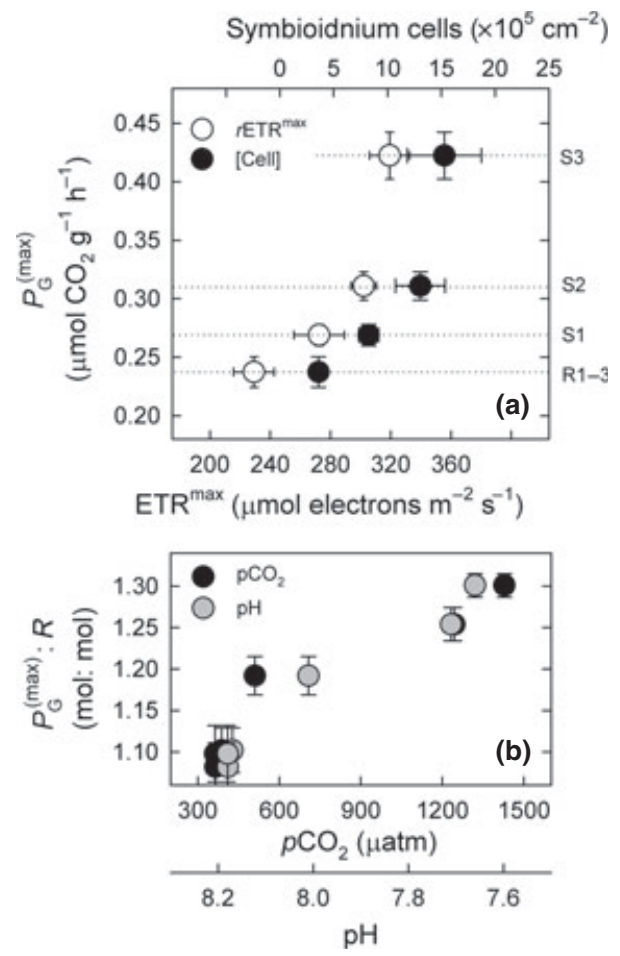

Fig. 2 Relationships of (a) the maximum rate of gross productivity $\left(P_{G}^{\max }, \mu \mathrm{mol} \mathrm{CO} \mathrm{CO}_{2} \mathrm{~g}^{-1} \mathrm{~h}^{-1}\right)$ vs. the maximum electron transfer rate $\left(\mathrm{ETR}^{\mathrm{max}}, \mu \mathrm{mol}\right.$ electrons $\left.\mathrm{m}^{-2} \mathrm{~s}^{-1}\right)$ and Symbiodinium cell density (cell $\times 10^{5} \mathrm{~cm}^{-2}$ tentacle) for the reference (R) and elevated $\mathrm{CO}_{2}(\mathrm{~S})$ sites at Vulcano. Note that each point is the mean \pm standard error of all replicates (and also that data for all of the reference sites, R1-R3 has been pooled for figure clarity); Bartlett's type II regression equations (and correlation coefficients) for these relationships were: $\mathrm{ETR}^{\max }=\left[\left(P_{G}^{\max } \cdot 518.1\right]+\right.$ $115.2\left(r^{2}=0.763, n=30, P<0.001\right)$; also $\mathrm{ETR}^{\max }=\left[\left(\right.\right.$ cells $\left.\times 10^{5}\right)$ . 7.542 $]+204.3\left(r^{2}=0.892, n=30, P<0.001\right) ; P_{G}^{\max }=[($ cells $\times$ $\left.\left.10^{5}\right) \cdot 0.191\right]+16.73\left(r^{2}=0.813, n=30, P<0.001\right)$; and $(b)$ the mean ( \pm standard) ratio of the maximum gross photosynthesis to respiration rate $\left(P_{G}^{\max }: \mathrm{R}, \mathrm{mol} \mathrm{CO}\right.$ fixed: $\mathrm{mol} \mathrm{CO} \mathrm{CO}_{2}$ released) vs. the median $p \mathrm{CO}_{2}$ and $\mathrm{pH}$ (see Table 1) across all sites. different from those at R3. Highest values of $\alpha$, ETR $^{\max }$ and $P_{G}^{\max }$ were observed at the highest $p \mathrm{CO}_{2}$ sites (S2-S3), ca. 0.65-0.70 mol electrons [mol photons] ${ }^{-1}$, 300-320 $\mu \mathrm{mol}$ electrons $\mathrm{m}^{-2} \mathrm{~s}^{-1}$ and $0.31-0.42 \mu \mathrm{mol}$ $\mathrm{CO}_{2} \mathrm{~g}^{-1} \mathrm{~h}^{-1}$.

Both measures of primary productivity, ETR ${ }^{\max }$ and $P_{G}^{\max }$, increased in proportion with $p \mathrm{CO}_{2}$ across the reference (R1-R3) sites, S1 and S2 (Fig. 2a); thus the yield of $\mathrm{CO}_{2}$ assimilation from PSII photosynthetic activity was highly conserved as $\mathrm{CO}_{2}$ increased $(\mathrm{pH}$ decreased). However, the increase of $P_{G}^{\max }$ (ca. 40\%) exceeded that of $\mathrm{ETR}^{\max }$ (ca. 10\%) between S2 and S3 indicating an increased yield of $\mathrm{CO}_{2}$ assimilation from PSII photosynthetic activity for the site with the highest $p \mathrm{CO}_{2}$.

Respiration rates also increased with $p \mathrm{CO}_{2}$, i.e. from ca. $0.22 \mu \mathrm{mol} \mathrm{CO} \mathrm{g}^{-1} \mathrm{~h}^{-1}$ (R1-3) to ca. 0.24-0.33 $\mu \mathrm{mol}$ $\mathrm{CO}_{2} \mathrm{~g}^{-1} \mathrm{~h}^{-1}$ (S1-S3) (Table 1); however, the increase of $\mathrm{R}$ was less than that of $P_{G}^{\max }$ such that the $P_{G}^{\max }: \mathrm{R}$ increased from ca. 1.1 at the reference sites to ca. 1.21.3 mol: mol from S1 to S3 (Table 2) and hence with increasing $p \mathrm{CO}_{2}$ (Fig. 2b). Both increases of $P_{G}^{\max }$ and $P_{G}^{\max }: \mathrm{R}$ suggest that greater anemone size/abundance with $p \mathrm{CO}_{2}$ may be driven, at least in part, by enhanced metabolic activity, and notably from increased primary productivity over respiration.

\section{Microalgal symbiont characteristics}

Symbiodinum populations across all sites/anemones were identified to be the same ITS2 'type' of clade A. This symbiont, designated here as A19, was previously isolated from the Mediterranean (Genbank accession 449046) and belongs to a lineage within clade A previously described as $\mathrm{A}^{\prime}$ that appears geographically restricted, yet regionally abundant, to the temperate locations of the Mediterranean and the north-eastern Atlantic (Savage et al., 2002; Visram et al., 2006). Thus, acclimation via a single Symbiodinium type regulates the enhanced primary productivity with lower $\mathrm{pH} /$ higher $\mathrm{CO}_{2}$.

Cell density (per $\mathrm{cm}^{-2}$ tentacle) was constant with tentacles containing ca. 3-4 $\times 10^{5}$ cells $\mathrm{cm}^{-2}$ for the reference sites R1-R3 but increased with $p \mathrm{CO}_{2}$ to 13 $15 \times 10^{5}$ cells $\mathrm{cm}^{-2}$ by S2-S3 (Table 2 ); cells contained ca. $20 \%$ more dividing cells at S3 compared to sites R1-R3 (mean \pm standard error mitotic index of $1.71 \pm 0.12 \%$ for R1-R3 vs. $2.08 \pm 0.18 \%$ for S3, $t$-test, $P<0.05$; not shown). Overall, the changes of Symbiodinium cell density were linearly correlated with those of ETR $^{\max }$ (and to a lesser extent $P_{G}^{\max }$ ), $r^{2}=0.892$ $\left(r^{2}=0.813\right.$ ) (see Fig. 2a) across all sites. As such, the increased $\mathrm{ETR}^{\max }$ (and $P_{G}^{\max }$ ) with $p \mathrm{CO}_{2} /$ decreasing $\mathrm{pH}$ was predominantly driven by increased Symbiodinium 
cell density as opposed to increased Symbiodinium productivity per cell.

\section{Discussion}

Anemones in present day benthic systems promote biodiversity by supporting mutualisms and numerous predators (e.g. Holbrook \& Schmitt, 2005), reducing macro- and filamentous-algal recruitment (Taylor \& Littler, 1982) and overgrowth (Bak \& Borsboom, 1984), and maintain primary productivity rates that can be as high as that of algae (Fitt et al., 1982). Thus, the enhanced metabolic activity (productivity) and, in turn growth (size and abundance), of anemones with increasing $p \mathrm{CO}_{2}$ /reduced $\mathrm{pH}$ suggest that $\mathrm{OA}$ could alter the role of anthozoans in benthic communities with fundamental implications to ecosystem function. At Vulcano, concomitant increases in anemone abundance with $p \mathrm{CO}_{2}$ corresponded with enhanced $P_{\mathrm{G}}$, i.e. a response comparable to that of the macroalgae at this site (Johnson et al., 2012). Although the increases in anemone abundance were perhaps not as pronounced as for the microalgae, the increase in $P_{\mathrm{G}}($ also $>\mathrm{R})$ would suggest that under $\mathrm{OA}$, anemones could contribute significantly to driving the ecosystem metabolism towards greater net autotrophy and $\mathrm{CO}_{2}$ sequestration. Such a biogeochemical response is potentially important in offsetting OA impacts to reef environments (Anthony et al., 2011), but this comes at a cost to the diversity of species and function.

Seawater acidification has been shown to reduce ecological diversity (e.g. Hall-Spencer et al., 2008; Fabricius et al., 2011), in particular where enhanced dissolution impedes growth of calcifying invertebrates (RodolfoMetalpa et al., 2011) and therefore limits their ability to keep the biomass of algae, or indeed other space competitors, in check. As non-calcifiers that supplement heterotrophy with autotrophy (although our higher values of $P_{\mathrm{G}}$ over $\mathrm{R}$ would suggest autotrophy dominates), anemones are already at an advantage over other invertebrates to lower $\mathrm{pH}$ conditions. Calcifying invertebrates that can compete under lower $\mathrm{pH}$ conditions inevitably exhibit reduced growth rates (Fabricius et al., 2011) as more energy is likely redirected to maintain calcification (e.g. Krief et al., 2010); however, in the case of the anemones their success via elevated productivity may be further exacerbated by their capacity to compete with algae for space via chemical deterrents (Bak \& Borsboom, 1984). Indeed, a decrease in macroalgal cover was observed at the highest $\mathrm{CO}_{2}$ site (S3), compared to S1 and S2, where the corresponding anemone abundance was almost a factor of 2 greater at $\mathrm{S} 3$ than at S1-S2. Anthozoans are well known for their aggressive control of space, perhaps giving soft-bodied anthozoan forms a competitive edge should they persist under $\mathrm{OA}$; such enhanced fitness could indeed be crucial where elevated $\mathrm{CO}_{2}$ already enhances algal competition (Diaz-Pulido et al., 2011; Johnson et al., 2012).

Of course understanding the driving mechanisms behind enhanced competition under $\mathrm{OA}$ also requires knowledge of whether or not anemone predation is also affected. Anemones are predated by a huge diversity of organisms, including crustaceans (decapods), molluscs (gastrapods), echinoderms (starfish) (e.g. Ottaway, 1977), which are all likely impacted at some stage of their life history by ocean acidification (e.g. Andersson et al., 2011). Unfortunately, little is known as to the predator-prey dynamics of Mediterranean A. viridis populations and thus we cannot presently address this issue; instead we focus on the enhanced $P_{\mathrm{G}}$, which clearly provides evidence for some fundamental role of $\mathrm{OA}$ in enhancing anemone success from the bottom up.

Regulation of anemone productivity by environmental factors such as light availability (e.g. Bythell et al., 1997; Muller-Parker \& Davy, 2001) is reasonably well understood; however, the role of $\mathrm{CO}_{2}(\mathrm{pH})$ has been largely neglected. Some OA-focussed lab experiments have been recently performed on temperate anemones of the temperate genus Anthopleura, but with contrasting results between studies/species: An increase of $P_{\mathrm{G}}$ and $\mathrm{R}$ (but $P_{\mathrm{G}}>\mathrm{R}$ ) as well as more abundant (and larger) Symbiodinium cells with decreasing $\mathrm{pH}$ were evident for Anthopleura elegantissima (Towanda \& Thuesen, 2012), i.e. results consistent with our observations at Vulcano for A. viridis. However, only small increases of Symbiodinium cell density and an increase of $\mathrm{R}$ exceeding that of $P_{\mathrm{G}}$ were observed at lower $\mathrm{pH}$ for A. aureoradiata (Doherty, 2009). Unfortunately, neither experiment was performed for long enough to determine whether either of these OA responses was conveyed into longer term differences in anemone fitness, such as growth and reproduction.

The underlying reason for these contrasting experimental results is not clear, and may simply reflect species-specific differences, but could equally reflect differences in conditions other than $\mathrm{CO}_{2}$ availability; for example, although both species were provided with similar feeding regimes (every 4-5 days), A. elegantissima and A. aureoradiata were maintained under temperature and light conditions of $12^{\circ} \mathrm{C}$ and $660 \mu \mathrm{mol}$ photons $\mathrm{m}^{-2} \mathrm{~s}^{-1}$ (14:10 L : D) and $16^{\circ} \mathrm{C}$ and $275 \mu \mathrm{mol}$ photons $\mathrm{m}^{-2} \mathrm{~s}^{-1}$ (12:12 L : D) respectively. Both light and temperature moderate the extent of $\mathrm{CO}_{2}$ uptake (and hence the likely responses observed to OA, e.g. Rodolfo-Metalpa et al., 2011) but it is not possible to determine which may be contributing to the contrasting responses from the data currently available. 
Our observations from Vulcano and those of Towanda \& Thuesen (2012) and Doherty (2009) would suggest that Symbiodinium productivity in anemones is limited by inorganic carbon $(i C)$ availability. As with other symbiotic cnidarians, Symbiodinium in anemones are separated from the external inorganic carbon supply by several membranes and thus limited by the supply of iC (e.g. Benazet-Tambutte et al., 1996; Muscatine et al., 1998; Davy \& Cook, 2001; see also Brownlee, 2009). To overcome $i C$ limitation the host cnidarian employs external (likely membrane-bound) carbonic anhydrase to convert $\mathrm{HCO}_{3}$ - to $\mathrm{CO}_{2}$ and enhance the $i \mathrm{C}$ supply from seawater to the Symbiodinium cells (e.g. Ganot et al. (2011) for A. viridis; see also Weis (1993), Weis \& Reynolds, 1999). Increased $i C$ availability promotes autotrophy $\left(P_{\mathrm{G}}\right)$, which in turn would increase the metabolic exchange with the host (Brownlee, 2009) and host respiration (Harland \& Davies, 1995). Such a response would be consistent with the greater OAinduced increase of $P_{\mathrm{G}}$ over $R$; that said, changes of $P_{\mathrm{G}}$ may not fully account for those of $R$, in particular where $P_{\mathrm{G}}$ does not fully meet the metabolic demands of the host (Davy et al., 1996). Although previous observations from the anemone A. elegantissima (Towanda \& Thuesen, 2012) suggest that the host receives more of their respiratory carbon from $P_{\mathrm{G}}$ under $\mathrm{OA}$, we cannot presently discount that differences in food supply (particulate organic carbon, POC) may also exist between reference and elevated sites to explain the differences of $\mathrm{R}$, and thus account for the relative role of $i \mathrm{C}$ vs. POC availability upon elevated growth.

Importantly the increased $P_{\mathrm{G}}$ with $p \mathrm{CO}_{2}$ observed here corresponded with enhanced Symbiodinium cell density whereas ETR ${ }^{\max }$ and $P_{G}^{\max }$ cell $^{-1}$ remained relatively constant. Symbiodinium can invest into enhanced growth (over cell-specific productivity) under OA (Brading et al., 2011) but such a response does not seem consistent with previous OA observations from calcifying anthozoans (e.g. Crawley et al., 2010; Krief et al., 2010; Meron et al., 2012) (see below). However, Symbiodinium cells are often nutrient-limited within (anemone) hosts, and the host environment likely setting the upper limit on the rate of Symbiodinium cell-cycle progression (Smith \& Muscatine, 1999; see also MullerParker \& Davy, 2001). Thus, increases in cell density can occur where densities are simply not optimum (at 'steady state' levels) and environmental conditions become more favourable for growth (Jones \& Yellowless, 1997; Muscatine et al., 1998); as such, Symbiodinium cell densities at the lowest $\mathrm{CO}_{2}$ sites could be lower than required for optimum growth. It is important to also note that our approach for normalizing Symbiodinium cell density to tentacle SA may influence how changes of $p \mathrm{CO}_{2}$ drive those of cell density. Specifically, tissue protein content per unit area appears to increase with $p \mathrm{CO}_{2}$ for both anemones (Towanda \& Thuesen, 2012) and scleractinian corals (Meron et al., 2012). Therefore, our observations of increased cells $\mathrm{cm}^{-2}$ with $p \mathrm{CO}_{2}$ may reflect the capacity of increased tissue content (per $\mathrm{cm}^{-2}$ tentacle) to simply harbour more cells. Even so Symbiodinium cell densities ultimately are increased with $p \mathrm{CO}_{2}$.

An increase of $P_{\mathrm{G}}$ with $\mathrm{CO}_{2}$, i.e. ' $\mathrm{CO}_{2}$ enrichment', is somewhat analogous to that expected from addition of other inorganic nutrients essential for Symbiodinium growth (Weis 1933); for example, $\mathrm{NH}_{4}{ }^{+}$additions have been repeatedly shown to increase Symbiodinium cell number and productivity by anemones (e.g. Cook et al., 1988; Muscatine et al., 1998, Smith \& Muscatine, 1999) suggesting that mutualistic associations occur between anemones and other organisms that excrete $\mathrm{NH}_{4}{ }^{+}$, e.g. anemone fish in tropical systems, provide nutritional benefits that can promote anemone growth (e.g. Holbrook \& Schmitt, 2005). In fact under extreme nutrient addition events, e.g. eutrophication of tropical reef systems, phase shifts dominated by enhanced anemone abundance can occur (Tkachenko et al., 2007). Such responses raise a critical point here:

Stimulation of productivity by inorganic carbon (OA) would require that nutrients such as nitrate and phosphate are available to build additional organic skeletons and thus 'fuel' the benefits of $\mathrm{CO}_{2}$ availability into growth; indeed, reports do exist of high $\mathrm{NH}_{4}{ }^{+}$excretion rates by temperate anemones (Jensen \& Muller-Parker, 1994), suggesting higher intrinsic nutrient availability/ storage inherent to temperate cnidaria (see also Davy et al., 2006) could support elevated $P_{\mathrm{G}}$ under OA, but such reports are rare. Stimulated growth of anemones can occur under increased nutrient availability without reductions of seawater $\mathrm{pH}$ (Tkachenko et al., 2007). In this case the actual benefit to the host, in terms of carbon translocated (and hence $\mathrm{R}$ ), may not increase unless more $\mathrm{CO}_{2}$ is available (Davy \& Cook, 2001). Our data does provide some evidence that nutrient availability may be enhanced at the lowest $\mathrm{pH}$ site since ETR ${ }^{\max }$ becomes more closely coupled with $P_{G}^{\max }$ (see Fig. 2); such a response is typical of stress relief, where electrons would otherwise be funnelled into alternative acceptors and/or cyclic flow (e.g. Suggett et al., 2011). So are the OA responses we observe at Vulcano potentially influenced by nutrient availability?

At present we cannot determine whether changes in particulate organic nutrient supply occur along the $\mathrm{CO}_{2}$ gradient; however, some data were collected for dissolved inorganic nutrients (nitrate plus nitrite, DIN, as well as phosphate, DIP) but not $\mathrm{NH}_{4}{ }^{+}$(L. Al-Moosawi, Personal communication) from surface samples during May 2011: DIP concentrations remained undetectable 
$(<10 \mathrm{nM})$ across the $\mathrm{pH}$ gradient. DIN concentrations also remained low (ca. $0.2 \mu \mathrm{M}$ ) for waters with a pH of 8.2-8.0, but did increase from ca. $0.2-0.8 \mu \mathrm{M}$ as $\mathrm{pH}$ decreased from 7.6 to 7.2 . Thus, it is possible that DIN concentrations are elevated periodically for $\mathrm{S} 3$ and, to a lesser extent, $\mathrm{S} 2$ (as per the $\mathrm{pH}$ range for these sites, Table 1). Even so, it is important to point out that (i) these elevated DIN concentrations at the lower $\mathrm{pH}$ are still somewhat low to sustain the substantially enhanced productivity here, (ii) a $\mathrm{CO}_{2}$ response is still observed for S1 where DIN concentrations are the same as for the reference sites, and (iii) the greater increase of $P_{G}^{\max }$ over ETR ${ }^{\max }$, potentially indicative of stress relief (possibly from DIN limitation) is only observed for S3. Thus, data would suggest that the primary response is to $p \mathrm{CO}_{2}$ but could be moderated by periodically elevated nitrogen availability at the high(est) $\mathrm{CO}_{2}$ sites; further verification is required and with a more detailed understanding of $p \mathrm{CO}_{2}$ and DIN (co)-variability. The previous laboratory studies examining the response of anemones to OA (Doherty, 2009; Towanda \& Thuesen, 2012) do not report DIN (DIP) and therefore it is unclear whether or not nutrient availability may also in part explain their somewhat contrasting observations.

Ocean acidification-induced stimulation of $P_{\mathrm{G}}$ from anemones would be generally consistent with observations from other cnidarians. Experiments simulating OA have frequently demonstrated that hermatypic (calcifying) corals exhibit increased primary productivity rates $\left(P_{\mathrm{N}}\right.$ and /or $\left.P_{\mathrm{G}}\right)$ with decreasing $\mathrm{pH}$ (e.g. Langdon \& Atkinson, 2005; Crawley et al., 2010; Krief et al., 2010; Rodolfo-Metalpa et al., 2010). However, these increases may often be relatively small, ca. 10-20\% increases with a twofold increase in $\mathrm{pCO}_{2}$ (Rodolfo-Metalpa et al., 2010) and/or, restricted to only moderate changes in $p \mathrm{CO}_{2}$ (Crawley et al., 2010); indeed some experiments have shown that $P_{\mathrm{G}}$ and/or $P_{\mathrm{N}}$ is either unchanged or can even decrease with increasing $p \mathrm{CO}_{2}$ (e.g. Schneider \& Erez, 2006). Such diversity of responses is perhaps not surprising since other factors likely regulating productivity, e.g. light availability (see Langdon \& Atkinson, 2005) and the role of calcification in modifying DIC availability (Schneider \& Erez, 2006; Krief et al., 2010), are again not well accounted for between experiments. Furthermore, reconciling these contrasting responses is confounded by a lack of knowledge of Symbiodinium genetic identity, which is almost never reported from coral OA studies but can fundamentally determine whether or not $P_{\mathrm{G}}$ is likely to respond to OA (Brading et al., 2011). Indeed, differences between Symbiodinium spp. may also explain why the OA response for anemones, i.e. enhanced $P_{\mathrm{G}}$ via increased cell density over productivity cell $^{-1}$, appears to differ from that previously observed for corals.
At Vulcano, enhanced $P_{\mathrm{G}}$ observed for the anemones was driven by increased growth (but not $P_{\mathrm{G}}$ cell ${ }^{-1}$ ) of a specific ITS2 type (A19) with $\mathrm{CO}_{2}$. Such a response of increased growth with $p \mathrm{CO}_{2}$ has been observed for another clade A-type, isolated from a tropical anemone (A13, Condylactis gigantea) (Brading et al., 2011); this same study also demonstrated enhanced $P_{\mathrm{G}}$ cell ${ }^{-1}$ for an A-type originally isolated from the scleractinian coral Montastrea faveolata, further suggesting that some clade A Symbiodinium may be particularly affected by OA. Thus, OA enhancement of productivity for anemones (and other non-calcifying cnidarians) may be expected where Symbiodinium within clade A dominates, such as in Mediterranean and/or European waters (Savage et al., 2002; Visram et al., 2006). Conservation of a single Symbiodinium type across natural $p \mathrm{CO}_{2}$ gradients is consistent with recent reports from scleractinian corals (Balanophyllia europaea and Cladocora caespitosa) at another Mediterranean vent site (Ischia, Meron et al., 2012); although whether or not this single type also exhibited enhanced $P_{\mathrm{G}}$ with $p \mathrm{CO}_{2}$ at Ischia is presently not known. The experiments by Fine \& Tchernov (2007) showing viable cnidarian growth under extremely low $\mathrm{pH}$ have only been demonstrated on Mediterranean corals to date.

Whether or not strong Symbiodinium driven responses of anthozoan productivity go beyond harbouring A-types in the Mediterranean is currently unknown; however, OA-induced stimulation of anemone productivity occurs with Symbiodinium from clade B as well (A. elegantissima, Towanda \& Thuesen, 2012). Even so, the strong OA response observed with Symbiodinium A19 at Vulcano could imply that OA enhanced productivity would perhaps not be as prominent in tropical reefs where anemones and other cnidarians, such as hard and soft corals, harbour genetically different symbionts within clade $\mathrm{A}$ in addition to those from other clades (e.g. Finney et al., 2010; LaJeunesse et al., 2010). Strong geographical and temporal delineations of Symbiodinium diversity do exist for anemone populations (Venn et al., 2009; Sanders \& Palumbi, 2011). Thus, further understanding how OA responses in cnidarians are moderated by symbiont identity will be key, in particular where specific phylotypes may further determine how cnidarians can respond to additional stressors, such as anomalous temperatures.

Overall, our data show that productivity and in turn growth of anthozoans can be substantially up-regulated by OA-like conditions; these factors appear to contribute, at least in part, to a bottom-up enhancement of anemone abundance in Vulcano's benthic community. Similar OA-induced enhancement of (non-calcifying) cnidarian abundance from other present day $\mathrm{CO}_{2}$ vent sites has not been previously observed (Hall-Spencer 
et al., 2008; Fabricius et al., 2011) but may represent a complex mix of factors regulating the responses; notably (i) ecological interactions modifying whether enhanced $P_{G}$ results in increased net growth/abundance (e.g. enhanced predation), (ii) interactive influences of other environmental conditions and (iii) Symbiodinium identity. How the responses we currently observe at Vulcano translate to broader (ecosystem)level responses by non-calcifying cnidarians under OA cannot currently be determined but is an obvious priority: Non-calcifying cnidarians, such as soft corals and anemones, can play key ecological and biogeochemical roles and often (re)populate reefs that have been impacted by local stressors (Tkachenko et al., 2007). Consequently, understanding how this group of organisms responds to longer term climatic change, and the combination of factor(s) that drives 'success' alongside elevated $p \mathrm{CO}_{2}$, will be an essential component of confidently predicting the future form and function of benthic ecosystems.

\section{Acknowledgements}

We wish to thank Marco Milazzo (University of Palermo) for essential academic and logistical support throughout. We are indebted to Simon Davy for critically reviewing and improving the final version of the manuscript. This work contributes to the EU FP7 project on 'Mediterranean Sea Acidification under a changing climate' (MedSeA grant agreement no. 265103) and to the UK Ocean Acidification Research Programme (NERC); also we gratefully acknowledge additional funding support by NERC (grant NE/G020116/1 to DJS and TL), Save Our Seas Foundation (JHS), The National Science Foundation (grant 1040940 to MEW) and The Earls Colne and Halstead Educational Charity (TGB).

\section{References}

Andersson AJ, Mackenzie FT, Gatusso J-P (2011) Effects of ocean acidification on benthic processes, organisms and ecosystems. In Gatusso J-P, Hansson L) (ed. Acidification Ocean), pp. 122-153. Oxford University Press Inc., New York.

Anthony KRN, Kline DI, Diaz-Pulido G, Dove S, Hoegh-Guldberg O (2008) Ocean acidification causes bleaching and productivity loss in coral reef builders. Proceedings of the National Academy of Sciences USA, 105, 17442-17446.

Anthony KRN, Kleypas JA, Gattuso JP (2011) Coral reefs modify their seawater carbon chemistry - implications for impacts of ocean acidification. Global Change Biol$o g y, \mathbf{1 7}, 3655-3666$

Bak RPM, Borsboom JLA (1984) Allelopathic interaction between a reef coelenterate and benthic algae. Oecologia, 63, 194-198.

Benazet-Tambutte S, Allemand D, Jaubert J (1996) Inorganic carbon supply to symbiont photosynthesis of the sea anemone, Anemonia viridis: role of the oral epithelial layers. Symbiosis, 20, 199-217.

Brading P, Davey P, Smith DJ et al. (2011) Differential impact of ocean acidification amongst phylotypes of Symbiodinium. Limnology \& Oceanography, 56, 927938

Brownlee C (2009) $\mathrm{pH}$ regulation in symbiotic anemones and corals: a delicate balancing act. Proceedings of the National Academy of Sciences USA, 106, 1654116542 .

Bythell JC, Douglas AE, Sharp VA, Searle JB, Brown BE (1997) Algal genotype and photoacclimatory responses of the symbiotic alga Symbiodinium in natural populations of the sea anemone Anemonia viridis. Proceedings of the Royal Society London B, 264, 1277-1282.
Caldeira K, Wickett ME (2005) Ocean model predictions of chemistry changes from carbon dioxide emissions to the atmosphere and ocean. Journal of Geophysical Research Oceans, 110, 1-2

Cigliano M, Gambi MC, Rodolfo-Metalpa R, Patti FP, Hall-Spencer JM (2010) Effects of ocean acidification on invertebrate settlement at volcanic $\mathrm{CO}_{2}$ vents. Marine Biology, 157, 2489-2502.

Connell SD, Russell BD (2010) The direct effects of increasing $\mathrm{CO}_{2}$ and temperature on non-calcifying organisms: increasing the potential for phase shifts in kelp forests. Proceedings of the Royal Society London B, 277, 1409-1415.

Cook CB, D'Elia CF, Muller-Parker G (1988) Host feeding and nutrient sufficiency for zooxanthellae in the sea anemone Aiptasia pallida. Marine Biology, 98, 253-262.

Crawley A, Kline DI, Dunn S, Anthony K, Dove S (2010) The effect of ocean acidification on symbiont photorespiration and productivity in Acropora Formosa. Global Change Biology, 16, 851-863.

Crook ED, Potts D, Rebolledo-Vieyra M, Hernandez L, Paytan A (2012) Calcifying coral abundance near low-pH springs: implications for future ocean acidification. Coral Reefs, 31, 239-245.

Davy SK, Cook CB (2001) The relationship between nutritional status and carbon flux in the zooxanthellate sea anemone Aiptasia pallida. Marine Biology, 139, 999 -1005 .

Davy SK, Lucas IAN, Turner JR (1996) Carbon budgets in temperate anthozoan- dinoflagellate symbioses. Marine Biology, 126, 773-783.

Davy SK, Withers KJT, Hinde R (2006) Effects of host nutritional status and seasonality on the nitrogen status of zooxanthellae in the temperate coral Plesiastrea versipora (Lamarck). Journal of Experimental Marine Biology and Ecology, 335, 256-265.

Diaz-Pulido G, Gouezo M, Tilbrook B et al. (2011) High $\mathrm{CO}_{2}$ enhances the competitive strength of seaweeds over corals. Ecology Letters, 14, 156-162.

Dickson AG (1990) Standard potential of the ( $\left.\mathrm{AgCl}+1 / 2 \mathrm{H}_{2}=\mathrm{Ag}+\mathrm{HCl}(\mathrm{aq})\right)$ cell and the association of bisulfate ion in synthetic sea water from 273.15 to $318.15 \mathrm{~K}$. Journal of Chemical Thermodynamics, 22, 113-127.

Doherty MJW (2009) Ocean acidification: Comparative impacts on the photophysiology of a temperate symbiotic sea anemone and a tropical coral. Unpublished MSc Thesis, Victoria University, Wellington, New Zealand, 168pp.

Edmunds PJ, Brown D, Moriarty B (2012) Interactive effects of ocean acidification and temperature on two scleractinian corals from Moorea French Polynesia. Global Change Biology, 18, 2173-2183.

Fabricius KE, Langdon C, Uthicke S et al. (2011) Losers and winners in coral reefs acclimatized to elevated carbon dioxide concentrations. Nature Climate Change, $\mathbf{1}$ 165-169.

Fine M, Tchernov D (2007) Scleractinian coral species survive and recover from decalcification. Science, 315, 1811

Finney JC, Pettay DT, Sampayo EM, Warner ME, Oxenford HA, LaJeunesse TC (2010) The Relative Significance of Host-Habitat, Depth, and Geography on the Ecology, Endemism, and Speciation of Coral Endosymbionts in the Genus Symbiodinium. Microbial Ecology, 60, 250-263.

Fitt WK, Pardy RL, Littler MM (1982) Photosynthesis, respiration, and contribution to community productivity of the asymbiotic sea anemone Anthopleura elegantissima. Journal of Experimental Marine biology \& Ecology, 61, 213-232.

Ganot P, Moya A, Magnone V, Allemand D, Furla P, Sabourault S (2011) Adaptations to endosymbiosis in a cnidarian-dinoflagellate association: Differential gene expression and specific gene duplications. PLoS Genet 7, doi: 10.1371/journal. pgen.1002187.

Hall-Spencer JM, Rodolfo-Metalpa R, Martin S et al. (2008) Volcanic carbon dioxide vents show ecosystem effects of ocean acidification. Nature, 454, 96-99.

Harland AD, Davies PS (1995) Symbiont photosynthesis increases both respiration and photosynthesis in the symbiotic sea anemone Anemonia viridis. Marine Biology, 123, 715-722.

Hennige SJ, Smith DJ, Perkins R, Consalvey M, Paterson DM, Suggett DJ (2008) Photoacclimation, growth and distribution of massive corals in clear and turbid waters. Marine Ecology Progress Series, 369, 77-88.

Hoegh-Guldberg O, Bruno JF (2010) The impact of climate change on the world's marine ecosystems. Science, 328, 1523-1528.

Holbrook SJ, Schmitt RJ (2005) Growth, reproduction and survival of a tropical sea anemone (Actiniaria): benefits of hosting anemonefish. Coral Reefs, 24, 67-73.

IPCC (Intergovernmental Panel on Climate Change) (2007) Working Group 1 Report, The Physical Science Basis. http://ipcc-wg1.ucar.edu/wg1/wg1-report.html.

Jensen SL, Muller-Parker G (1994) Inorganic nutrient fluxes in anemone-dominated tide pools. Pacific Science, 48, 32-43.

Johnson VR, Brownlee C, Rickaby REM, Graziano M, Milazzo M, Hall-Spencer JM (2011) Responses of marine benthic microalgae to elevated $\mathrm{CO}_{2}$. Marine Biology, doi: 10.1007/s00227-011-1840-2 
Johnson VR, Russell BD, Fabricius KE, Brownlee C, Hall-Spencer JM (2012) Temperate and tropical brown macroalgae thrive, despite decalcification, along natural $\mathrm{CO}_{2}$ gradients. Global Change Biology, doi: 10.1007/s00227-011-1840-2.

Jones RJ, Yellowless D (1997) Regulation and control of intracellular algae (= zooxanthellae) in hard corals. Philosophical Transactions of the Royal Society London B, 352, 457-468.

Krief S, Hendy EJ, Fine M, Yam R, Meibom A, Foster GL, Shemesh A (2010) Physiological and isotopic responses of scleractinian corals to ocean acidification. Geochimica Geophysica Acta, 74, 4988-5001.

Kroeker KJ, Micheli F, Gambi MC, Martz TR (2011) Divergent ecosystem responses within a benthic marine community to ocean acidification. Proceedings of the National Academy of Sciences USA, 108, 14515-14520.

LaJeunesse T (2002) Diversity and community structure of symbiotic dinoflagellates from Caribbean coral reefs. Marine Biology, 141, 387-400.

LaJeunesse TC, Trench RK (2000) The biogeography of two species of Symbiodinium (Freudenthal) inhabiting the intertidal anemone, Anthopleura elegantissima (Brandt). Biological Bulletin, 199, 126-134.

LaJeunesse T, Loh WKW, van Woesik R, Heogh-Guldberg O, Schmidt GW, Fitt WK (2003) Low symbiont diversity in southern Great Barrier Reef corals, relative to those of the Caribbean. Limnology \& Oceanography, 48, 2046-2054.

LaJeunesse TC, Pettay DT, Sampayo EM et al. (2010) Long-standing environmental conditions, geographic isolation and host-symbiont specificity influence the relative ecological dominance and genetic diversification of coral endosymbionts in the genus Symbiodinium. J. Biogeogr., 37, 785-500.

Langdon C, Atkinson MJ (2005) Effect of elevated $\mathrm{pCO}_{2}$ on photosynthesis and calcification of corals and interactions with seasonal change in temperature/irradiance and nutrient enrichment. Journal of Geophysical Research, 110, 1-16.

Lewis E, Wallace WR (1998) Program developed for $\mathrm{CO}_{2}$ system calculations. Carbon dioxide information analysis center, Oak Ridge National Laboratory, U.S. Department of Energy, Oak Ridge, TN.

Meron D, Rodolfo-Metalpa R, Cunning R, Baker AC, Fine M, Banin E (2012) Changes in coral microbial communities in response to a natural $\mathrm{pH}$ gradient. ISME Journal, doi: 10.1038/ismej.2012.19.

Muller-Parker M, Davy SK (2001) Temperate and tropical algal-sea anemone symbioses. Invertebrate Biology, 120, 104-123.

Muscatine L, Ferrier-Pagès C, Blackburn CA, Gates RD, Baghdasarian G, Allemand D (1998) Cell-specific density of symbiotic dinoflagellates in tropical anthozoans. Coral Reefs, 4, 329-337.

Ottaway JR (1977) Predators of sea anemones. Tuatara, 22, 213-220.

Rodolfo-Metalpa R, Martin S, Ferrier-Pagès C, Gattuso J-P (2010) Response of the temperate coral Cladocora caespitosa to mid- and long-term exposure to $\mathrm{pCO}_{2}$ and temperature levels projected for the year $2100 \mathrm{AD}$. Biogeosciences, 7, 289-300.

Rodolfo-Metalpa R, Houlbre que F, Tambutté E et al. (2011) Coral and mollusc resistance to ocean acidification adversely affected by warming. Nature Climate Change, 1, 308-312.

Roy RN, Vogel KM, Porter-Moore C et al. (1993) The dissolution of constants of carbonic acid in seawater at salinities 5 to 45 and temperatures 0 to $45{ }^{\circ} \mathrm{C}$. Marine Chemistry, 4, 249-267.
Sanders JG, Palumbi SR (2011) Populations of Symbiodinium muscatinei show strong biogeographic structuring in the intertidal anemone Anthopleura elegantissima. Biological Bulletin, 220, 199-208.

Savage AM, Goodson AS, Visram S, Trapido-Rosenthal H, Wiedenmann J, Douglas $\mathrm{AE}$ (2002) Molecular diversity of symbiotic algae at the latitudinal margins of their distribution: dinoflagellates of the genus Symbiodinium in corals and sea anemones. Marine Ecology Progress Series, 244, 17-26.

Schneider K, Erez J (2006) The effect of carbonate chemistry on calcification and photosynthesis in the hermatypic coral Acropora eurystoma. Limnology \& Oceanography, 51, 1284-1293.

Smith GJ, Muscatine L (1999) Cell cycle of symbiotic dinoflagellates: variation in G1 phase-duration with anemone nutritional status and macronutrient supply in the Aiptasia pulchella-Symbiodinium pulchrorum symbiosis. Marine Biology, 134, 405-418.

Suggett DJ, Moore CM, Hickman AE, Geider RJ (2009) Interpretation of Fast Repetition Rate (FRR) fluorescence: signatures of community structure vs. physiological state. Marine Ecology Progress Series, 376, 1-19.

Suggett DJ, Moore CM, Geider RJ (2011) Estimating aquatic primary productivity using active fluorescence. In Chlorophylla fluorescence in aquatic sciences: methods and applications (eds. Suggett DJ, Prasil O, Borowitzka MA), pp. 103-127. Springer, Berlin.

Suggett DJ, Kikuchi RKP, Oliveira MDM et al. (2012) Photobiology of corals from Brazil's near-shore marginal reefs of Abrolhos. Marine Biology, 159, 1461-1473.

Taylor PR, Littler MM (1982) The roles of compensatory mortality, physical disturbance, and substrate retention in the development and organization of a sandinfluenced rocky intertidal community. Ecology, 63, 135-146.

Tkachenko KS, Wu BJ, Fang LS, Fan TY (2007) Dynamics of a coral reef community after mass mortality of branching Acropora corals and an outbreak of anemones. Marine Biology, 151, 185-194.

Towanda T, Thuesen EV (2012) Prolonged exposure to elevated $\mathrm{CO}_{2}$ promotes growth of the algal symbiont Symbiodinium muscatinei in the intertidal sea anemone Anthopleura elegantissima. Biology Open, doi: 10.1242/bio.2012521.

Venn AE, Loram JE, Trapido-Rosenthal HG, Joyce DA, Douglas AE (2009) Importance of Time and Place: patterns in Abundance of Symbiodinium Clades A and B in the Tropical Sea Anemone Condylactis gigantean. Biological Bulletin, 215, 243-252.

Visram A, Wiedenmann J, Douglas AE (2006) Molecular diversity of symbiotic algae of the genus Symbiodinium (Zooxanthellae) in cnidarians of the Mediterranean Sea. Journal of the Marine biological Association UK, 86, 1281-1283.

Weis VM (1993) Effect of dissolved inorganic carbon concentration on the photosynthesis of the symbiotic sea anemone Aiptasia pulchella Carlgren: role of carbonic anhydrase. Journal of Experimental Marine Biology and Ecology, 174, 209-225.

Weis VM, Reynolds WS (1999) Carbonic anhydrase expression and synthesis in the sea anemone Anthopleura elegantissima are enhanced by the presence of dinoflagellate symbionts. Physiological \& Biochemical Zoology, 72, 307-316

Weis VM, Davy SK, Hoegh-Guldberg O, Rodriguez-Lanetty M, Pringle JR (2008) Cell biology in model systems as the key to understanding corals. Trends in Ecology $\mathcal{E}$ Evolution, 23, 369-376. 